\title{
PRECISION OF HIGH-RESOLUTION DUAL ENERGY X-RAY ABSORPTIOMETRY MEASUREMENTS OF BONE MINERAL STATUS AND BODY COMPOSITION IN SMALL ANIMAL MODELS
}

\author{
E.-M. Lochmüller ${ }^{*}$, V. Jung ${ }^{1,2}$, A. Weusten ${ }^{1,2}$, U. Wehr $^{3}$, E. Wolf ${ }^{4}$ and F. Eckstein ${ }^{2}$ \\ ${ }^{1}$ Universitätsfrauenklinik, Innenstadt, ${ }^{2}$ Musculoskeletal Research Group, Anatomische Anstalt, \\ ${ }^{3}$ Institut für Physiologie, Physiologische Chemie und Tierernährung, \\ ${ }^{4}$ Institut für Molekulare Tierzucht und Haustiergenetik, Genzentrum, \\ Ludwig-Maximilians-Universität München, Germany
}

\begin{abstract}
The purpose of this study was to analyze the in situ precision (reproducibility) of bone mineral and body composition measurements in mice of different body weights and rats, using a high-resolution DXA (dual energy X-ray absorptiometry) scanner. We examined 48 NMRI mice weighing approximately 10 to $60 \mathrm{~g}$, and 10 rats weighing approximately $140 \mathrm{~g}$. Four repeated measurements were obtained on different days. In mice, the standard deviations of repeated measurements ranged from 2.5 to 242 $\mathrm{mg}$ for bone mineral content (BMC), from 0.16 to $3.74 \mathrm{~g}$ for fat, and from 0.40 to $4.21 \mathrm{~g}$ for lean mass. The coefficient of variation in percent (CV\%) for BMC/BMD (bone mineral density) was highest in the $10 \mathrm{~g}$ mice $(12.8 \% /$ $4.9 \%)$ and lowest in the $40 \mathrm{~g}$ mice $(3.5 \% / 1.7 \%)$. In rats, it was $2.5 / 1.2 \%$ in the lower extremity, $7.1 / 3.0 \%$ in the spine, $5.7 / 2.0 \%$ in the femur, and $3.6 \% / 2.1 \%$ in the tibia. The $\mathrm{CV} \%$ for fat and lean mass in mice was higher than for BMC. The study demonstrates good precision of bone mineral and moderate precision of body composition measure-ments in small animals, using a high-resolution DXA system. The technique can be used for testing the efficacy of drugs in small animal models, for muta-genesis screens, and for the phenotypic characterization of transgenic mice.
\end{abstract}

Key Words: Small animals, mouse, rat, dual energy X-ray absorptiometry, bone, fat, bone mineral, precision.

\footnotetext{
*Address for correspondence:

Eva-Maria Lochmüller

I. Universitätsfrauenklinik

Maistrasse 11, D-80337 München, Germany

Telephone Number: ++ 498951604847

FAX Number: ++ 498951604802

E-mail: eckstein@anat.med.uni-muenchen.de
}

\section{Introduction}

Osteoporosis is the most widespread disease of the skeletal system with approximately one third of all postmenopausal women being currently affected in the USA and in Europe (Cooper and Barret-Connor, 1996). At the age of eighty, $60 \%$ of all women have sustained a fracture (Cooper und Barret-Connor, 1996), 90\% of which can be attributed to osteoporotic bone changes (Melton et al., 1997). The total costs involved in osteoporotic fractures have been estimated to currently amount to 13 billion US\$ in the United States (Ray et al., 1997), and due to the future demographic development, these costs are expected to increase considerably throughout the next century (Cooper et al., 1992).

Several drugs are now available to counteract osteoporotic bone loss and bone fracture risk, and animal models have become an invaluable tool both for testing the efficacy of these drugs as well as for analyzing the role of different genes and gene products on bone metabolism and bone mineral status. A promising approach for the discovery of new and more effective compounds is to identify the key molecular targets, for instance by screening genetically altered mice in vivo (mutagenesis screen programs Hrabé de Angelis et al., 2000) or by examining animals, in which specific genes have been deleted or overexpressed (Amling et al., 1998; Mundy, 1998; Chang, 1999). The mouse has become a particularly popular model system in this context, because it is genetically, developmentally and biochemically similar to the human. It is possible to randomly alter its genome (Hrabé de Angelis et al., 2000) and to selectively delete (knock-outs) or introduce (transgenesis) specific genes (Rossant and Nagy, 1995; Wynshaw-Boris, 1996; Amling et al., 1998; Chang, 1999).

In the ovariectomized rat, the bone mineral content and density have been shown to decrease rapidly in comparison with sham operated animals, and this model has thus been widely used to test the effect of various therapeutic compounds on bone status (Kalu, 1991; Chow et al., 1992; Abe et al., 1993; Shen et al., 1995; Kinney et al., 1998; Kapadia et al., 1998).

The effectiveness with which differences or changes in bone mineral status can be detected in vivo in these animal models, however, depends on the precision of the particular technique in measuring bone mass or density. The method of dual energy X-ray absorptiometry (DXA) has been brought into clinical practice in the eighties and pro- 
vided the first quantitative measures of bone mineral by using two separate energy levels. It is now the most widespread technique to diagnose bone loss in humans (Genant et al., 1996; Adams, 1997) and currently serves as a basis for the operational definition of osteoporosis by the WHO (- 2.5 standard deviations from young adults). More recently, "small animal software" has been developed for clinical DXA scanners, and this has been applied to several animals, particularly the rat (e.g., Grier et al., 1996; Rozenberg et al., 1995; Makan et al., 1997). However, measurements in mice have been very limited with this technique due to their relatively small body dimensions. Klein et al. (1998) recently examined carcasses of mice (without skin, organs and soft tissues) weighing 10 to $24 \mathrm{~g}$ with DXA, but there exists no comprehensive study into the precision of DXA measurements in intact mice of different body weights, to estimate the reliability of in vivo measurements.

The objective of the current study was therefore to apply and test a new high-resolution DXA scanner, and to analyze the precision (reproducibility) of bone mineral measurements in mice of different ages and body weights. Precision tests were also performed for various subregions of the rat (lower extremities, lumbar spine, femur, and tibia). Repeated measurements were performed on different days after recalibration of the system, with repositioning of the animals in between replicate scans.

\section{Materials and Methods}

\section{Animals}

A total of 48 mice and 10 rats were examined in this study. The mice were Naval Medical Research Institute (NMRI) outbred mice (Charles River-Wiga, Sulzfeld, Germany) and kept under conventional (non-barrier) conditions. They had free access to tap water and a standard rodent diet (Ssniff V1126, Soest, Germany) and were finally sacrificed under painless conditions by cervical dislocation and stored at $-20^{\circ} \mathrm{C}$ until examination. The first group of mice $(\mathrm{N}=10)$ were two weeks old with an average body weight of $8.9 \pm 0.59 \mathrm{~g}$ (range 7.8 to $9.9 \mathrm{~g}$ ) [group 1 , and for simplicity termed $10 \mathrm{~g}$ mice]. The second group of mice were 4 weeks old $(\mathrm{N}=10)$ with an average weight of $21.0 \pm 1.4 \mathrm{~g}$ (range 19.6 to $23.4 \mathrm{~g}$ ) [group $2=20 \mathrm{~g}$ mice]. The third group consisted of adult mice aged 14 weeks $(\mathrm{N}=14)$ with a body weight of $37.5 \pm 4.3 \mathrm{~g}$ (range 28.8 to $43.9 \mathrm{~g}$ ) [group $3=40 \mathrm{~g}$ mice], and the fourth of 14 week old hemizygous bovine growth hormone transgenic mice $(\mathrm{N}=14$ with an average weight of $62.0 \pm 8.3 \mathrm{~g}$ (range 51.1 to $78.9 \mathrm{~g}$ ) [group $4=60 \mathrm{~g}$ mice]. These were obtained from the 14th generation of sequential crossing of mouse metallothionein promotor-bovine growth hormone transgenic mice and kindly provided by Dr. T.E. Wagner (Edison Biotechnology Center, Ohio University, Athens, Ohio, USA).

The rats $(\mathrm{N}=10)$ were Fischer 344 inbred rats aged 6 weeks, with an average body weight of $137 \pm 6.9 \mathrm{~g}$ (range 128 to $153 \mathrm{~g}$ ). These were obtained from IFFA CREDO
(Saint-German sur l'Arbresle, France). The animals were also kept under conventional conditions with unlimited access to tap water and standard rodent diet and were sacrificed painlessly by ether inhalation. Storage was again at $20^{\circ} \mathrm{C}$ until examination.

All experiments were performed according to the German Animal Protection Law.

\section{High-resolution DXA scanner}

The bone mineral analysis was performed with a highresolution DXA scanner (pDEXA Sabre, Norland/Stratec, Stratec Medizintechnik, Pforzheim, Germany) that has been specifically adapted to the analysis of small animals. The scanner uses a $50 \times 150 \mu \mathrm{m}$ focal spot X-ray tube (acceleration voltage: $60 \mathrm{kV}$, anode current: $250 \mu \mathrm{A}$ ) and a Kedge filtering technique $(250 \mu \mathrm{m} \mathrm{Sn})$ to separate the emitted energy spectrum into two distinct energy peaks of 28 $\mathrm{keV}$ and $48 \mathrm{keV}$, respectively. Within a 12 x 15 centimeter measurement field, the transmitted energy is detected by a cadmium-telluride twin-detector assembly mounted on the same $\mathrm{C}$-arm as the X-ray source. Based on the attenuation of the two energy levels, the system provides quantitative data on the bone mineral content (BMC), the fat tissue content, the lean tissue content, and (by adding these three values) the total tissue mass within the region of interest. By delineating the projectional area of the bones, the software additionally provides the areal bone mineral density $\left(\mathrm{BMD}\right.$ in $\left.\mathrm{g} / \mathrm{cm}^{2}\right)$ [Note that the DXA BMD is a projectional value and not a true volumetric measurement; it is therefore not independent of bone size]. Bone mineral values can be derived for the total scan field and, additionally, for an arbitrary number of subregions, which can be interactively selected within the projectional image. The scan speed can be varied between 1 and $40 \mathrm{~mm} / \mathrm{sec}$, and the resolution between $0.1 \mathrm{~mm} \times 0.1 \mathrm{~mm}(2.5 \times 2.5 \mathrm{~cm}$ scan field ) and $0.5 \mathrm{~mm} \times 1.0 \mathrm{~mm}(12 \times 15 \mathrm{~cm}$ scan field [matrix $255 \times 255$ pixels].

\section{Study protocol}

All measurements were carried out four times and on different days (after recalibration of the system). For measuring the body composition and total $\mathrm{BMC}$ of the mice, the animals were thawed to room temperature before the investigation and positioned supine on the scanner, the extremities being abducted and positioned flat on the table. The resolution was adapted to the size of the animals and the scan speed was selected in a way that the total scan time (including positioning and acquisition of a scout view) did not exceed $20 \mathrm{~min}$. The reason for this was that for this period animals can be readily anesthetized by intraperitoneal injection and could be examined under identical conditions in vivo. For group 1 (10 g mice), the scan speed was $5 \mathrm{~mm} / \mathrm{s}$ and the resolution $0.5 \times 0.5 \mathrm{~mm}$, for group 2 (20 g mice) the scan speed $10 \mathrm{~mm} / \mathrm{s}$ and the resolution also $0.5 \times 0.5 \mathrm{~mm}$, for group 3 (40 g mice) $20 \mathrm{~mm} / \mathrm{s}$ and the resolution $0.5 \times 1.0 \mathrm{~mm}$, and for group 4 (60 g mice) both parameters identical to group 3 . The entire skeleton was analyzed in all cases. The DXA results obtained for total body weight $(\mathrm{BMC}+$ fat tissue content + lean tissue content) were directly compared with body weights obtained on a high-precision laboratory scale (Mettler PM 100, Mettler, Giessen, Germany). 


\begin{tabular}{|l|l|l|l|l|l|}
\hline & $\begin{array}{l}\text { BMC } \\
(\mathrm{mg})\end{array}$ & $\begin{array}{l}\text { BMD } \\
\left(\mathrm{mg} / \mathrm{cm}^{2}\right)\end{array}$ & $\begin{array}{l}\text { Fat Mass } \\
(\mathrm{g})\end{array}$ & $\begin{array}{l}\text { Lean Mass } \\
(\mathrm{g})\end{array}$ & $\begin{array}{l}\text { Total Tissue Mass } \\
\text { Difference to }(\mathrm{g})\end{array}$ \\
\hline $\begin{array}{l}\text { Group 1 } \\
{[10 \mathrm{~g} \text { mice }]}\end{array}$ & $\begin{array}{l}86.9 \pm 6.49 \\
(75.2 / 96.8)\end{array}$ & $\begin{array}{l}32.8 \pm 1.29 \\
(30.7 / 34.2)\end{array}$ & $\begin{array}{l}1.31 \pm 0.30 \\
(0.80 / 1.67)\end{array}$ & $\begin{array}{l}5.84 \pm 0.56 \\
(5.01 / 6.62)\end{array}$ & $\begin{array}{l}-1.73 \\
(-2.15 /-1.33)\end{array}$ \\
\hline $\begin{array}{l}\text { Group 2 } \\
{[20 \text { g mice }]}\end{array}$ & $318 \pm 40.0$ & $43.0 \pm 1.43$ & $43.0 \pm 1.43$ & $16.6 \pm 0.72$ & -0.99 \\
\hline Group 3 & $(271 / 391)$ & $(41.2 / 46.0)$ & $(2.31 / 3.95)$ & $(15.9 / 18.1)$ & $(-1.53 /-0.48)$ \\
{$[40$ g mice $]$} & $(772 / 1238)$ & $(772 / 1238)$ & $(3.96 / 23.8)$ & $(8.32 / 30.8)$ & -2.45 \\
\hline Group 4 & $1654 \pm 265$ & $71.3 \pm 4.2$ & $17.4 \pm 10.0$ & $40.9 \pm 12.6$ & -2.06 \\
{$[60$ g mice $]$} & $(1296 / 2185)$ & $(64.7 / 77.3)$ & $(4.04 / 35.3)$ & $(19.4 / 58.9)$ & $(-2.43 /-1.50)$ \\
\hline
\end{tabular}

\footnotetext{
* Body weight measured on a high-precision scale prior to scanning; Group $1=10$ mice, 2 weeks old, body weight $8.9 \pm 0.6 \mathrm{~g}$; Group $2=10$ mice, 4 weeks old, body weight $21.0 \pm 1.4 \mathrm{~g}$; Group $3=14$ mice, 12 weeks old, body weight $37.5 \pm 4.3 \mathrm{~g}$; Group $4=14 \mathrm{GH}$ transgenic mice, 12 weeks old, body weight $62 \pm 8.3 \mathrm{~g}$
}

Table 1. Results of the in situ analysis of the body composition and bone mineral content of mice of different body weights (group 1 to 4 ) with high-resolution DXA. Mean values \pm standard deviation and range (in brackets)

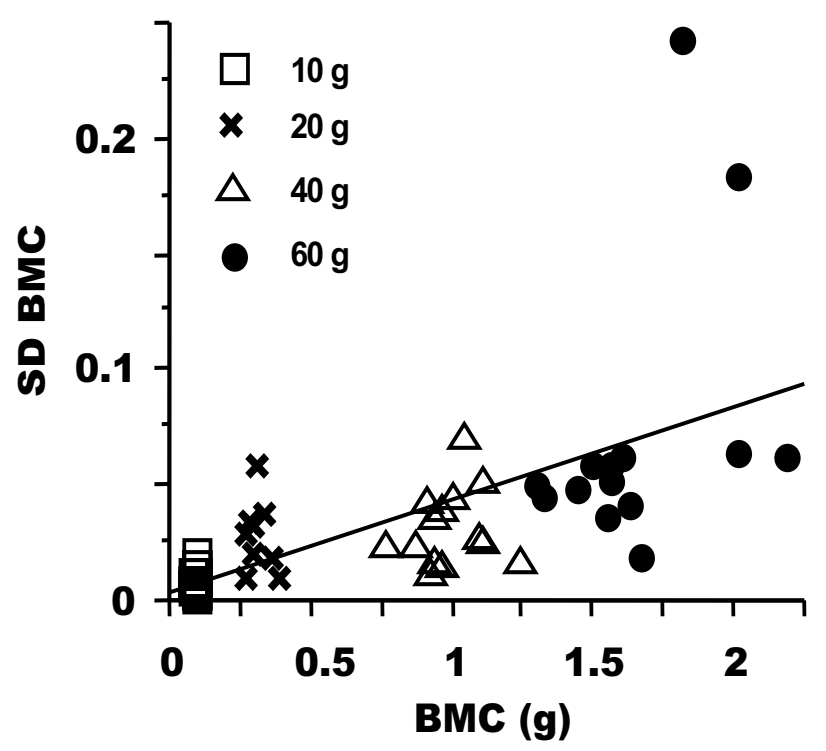

Figure 1. Graph showing the standard deviations of four repeated measurements of bone mineral content (BMC) in mice as a function of the absolute values (measurement on different days, after repositioning of the animals). The standard deviations of repeated measurements can be related to the differences of the animals within and between the groups.

Since the total length of the rats exceeded the scan field, only parts of the animals could be investigated under in situ conditions. The measurements were thus performed for a region of interest that covered the lower body skeleton, including the lumbar spine, the pelvis, the lower extremities, and the tail of the animals. The scan speed was set to $20 \mathrm{~mm} / \mathrm{sec}$ and the resolution to $0.5 \times 1.0 \mathrm{~mm}$. After the scanning, analyses were carried out for the total field and for several subregions (lower extremities only, the lumbar spine, left femur, left tibia).

\section{Statistical analysis}

For determining the precision (reproducibility) of the measurements, the four values obtained on different days for each of the parameters were averaged in each animal. The standard deviation (SD) of the four repeated measurements was determined, and related to the mean value, giving the coefficient of variation in percent $(\mathrm{CV} \%)$. To calculate the average SD and $\mathrm{CV} \%$ for each parameter in each set of animals, the root-mean-square (RMS) average SD/ $\mathrm{CV} \%$ (not the arithmetic mean) was determined as described by Glüer et al. (1995). To analyze the relationship between body weight and precision, and between bone mineral content and precision, we applied linear regression analyses (Statview 4.5, Abacus Concepts, Berkeley, CA).

\section{Results}

\section{In situ analysis of entire mice}

The BMC in the 48 mice (as measured by HR-DXA) ranged from 75 to $2185 \mathrm{mg}$, the BMD from 31 to $77 \mathrm{mg} /$ $\mathrm{cm}^{2}$, the fat tissue mass from 0.80 to $35.3 \mathrm{~g}$, the lean tissue mass from 5.01 to $58.9 \mathrm{~g}$ (Table 1; Figs. 1-3).

Compared with the weight measured on the scale, the total tissue mass was underestimated with DXA by between -3.06 and $-0.48 \mathrm{~g}$ (Table 1 ), with a percentage underestimation of $19.2 \%$ in the $10 \mathrm{~g}$ mice, but deviations of less than $7 \%$ in the other groups (Table 3; Fig. 4). The correlation between the total tissue mass determined with DXA and the body weight on the scale was 0.92 (standard error of the estimate $=0.25 \mathrm{~g} / \mathrm{SEE} \%=2.8 \%$ ) for the $10 \mathrm{~g}$ 


\begin{tabular}{|c|c|c|c|c|c|}
\hline & $\begin{array}{l}\text { BMC } \\
(\mathrm{mg})\end{array}$ & $\begin{array}{l}\text { BMD } \\
\left(\mathrm{mg} / \mathrm{cm}^{2}\right)\end{array}$ & $\begin{array}{l}\text { Fat } \\
(\mathrm{g})\end{array}$ & $\begin{array}{l}\text { Lean } \\
(\mathrm{g})\end{array}$ & $\begin{array}{l}\text { Total Tissue } \\
\text { (g) }\end{array}$ \\
\hline $\begin{array}{l}\text { Group } 1 \\
{[10 \mathrm{~g} \text { mice }]}\end{array}$ & $\begin{array}{l}11.2 \\
(2.45 / 21.0)\end{array}$ & $\begin{array}{l}1.77 \\
(0.70 / 2.75)\end{array}$ & $\begin{array}{l}0.56 \\
(0.16 / 0.80)\end{array}$ & $\begin{array}{l}1.05 \\
(0.63 / 1.63)\end{array}$ & $\begin{array}{l}0.56 \\
(0.27 / 0.99)\end{array}$ \\
\hline $\begin{array}{l}\text { Group } 2 \\
\text { [20 g mice] }\end{array}$ & $\begin{array}{l}30.1 \\
(8.06-57.6)\end{array}$ & $\begin{array}{l}1.96 \\
(0.82 / 2.94)\end{array}$ & $\begin{array}{l}0.81 \\
(0.21 / 1.27)\end{array}$ & $\begin{array}{l}0.99 \\
(0.44 / 1.54)\end{array}$ & $\begin{array}{l}0.31 \\
(0.11 / 0.65)\end{array}$ \\
\hline $\begin{array}{l}\text { Group } 3 \\
\text { [40 g mice] }\end{array}$ & $\begin{array}{l}34.8 \\
(10.9 / 70.2)\end{array}$ & $\begin{array}{l}1.11 \\
(0.50 / 1.71)\end{array}$ & $\begin{array}{l}1.06 \\
(0.38 / 1.55)\end{array}$ & $\begin{array}{l}1.03 \\
(0.44 / 1.58)\end{array}$ & $\begin{array}{l}0.34 \\
(0.10 / 0.71)\end{array}$ \\
\hline $\begin{array}{l}\text { Group } 4 \\
\text { [60 g mice] }\end{array}$ & $\begin{array}{l}94.4 \\
(18.8 / 242)\end{array}$ & $\begin{array}{l}2.27 \\
(0.50 / 4.57)\end{array}$ & $\begin{array}{l}1.82 \\
(0.18 / 3.74)\end{array}$ & $\begin{array}{l}1.88 \\
(0.40 / 4.21)\end{array}$ & $\begin{array}{l}0.45 \\
(0.16 / 0.65)\end{array}$ \\
\hline
\end{tabular}

See legend of Table 1

Table 2. Precision of the in situ analysis of the body composition and bone mineral content of mice of different body weights (group 1 to 4) with high-resolution DXA. Root-mean-square average of the standard deviations of repeated measurements (and range).

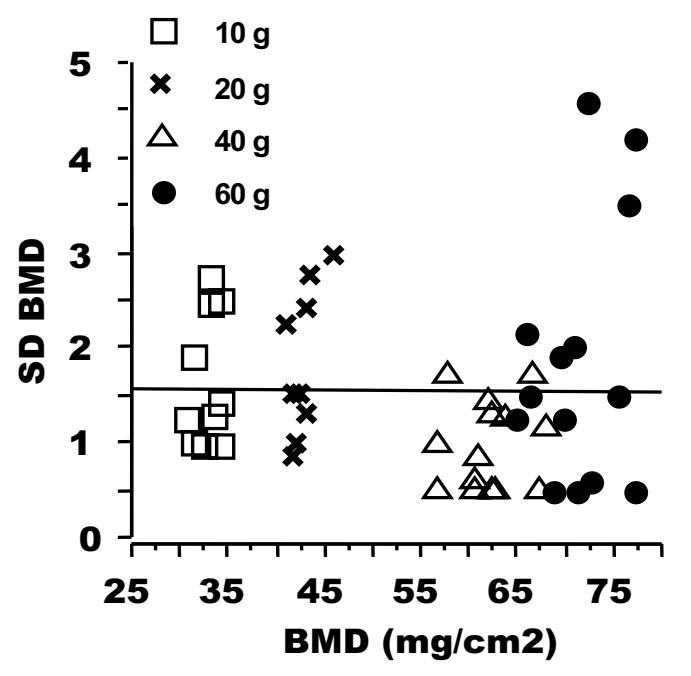

Figure 2. Graph showing the standard deviations of four repeated measurements of areal bone mineral density (BMD) in mice as a function of the absolute values. Same conditions and groups as indicated in the legend of Figure 1.

mice, 0.97 for the $20 \mathrm{~g}$ mice $(\mathrm{SEE}=0.36 \mathrm{~g}=1.7 \%), 0.99$ for the $40 \mathrm{~g}$ mice $(\mathrm{SEE}=0.62 \mathrm{~g}=1.6 \%), 0.99$ for the 60 $\mathrm{g}$ mice $(\mathrm{SEE}=0.26 \mathrm{~g}=0.4 \%)$, and 0.99 for all animals taken together $(\mathrm{SEE}=0.69 \mathrm{~g}=1.9 \%)($ Fig. 4$)$.

The standard deviations of repeated DXA measurements ranged from 2.5 to $242 \mathrm{mg}$ for the total $\mathrm{BMC}$, from 0.50 to $4.57 \mathrm{mg} / \mathrm{cm}^{2}$ for the BMD, from 0.16 to $3.74 \mathrm{~g}$ for the fat tissue content, from 0.40 to $4.21 \mathrm{~g}$ for the lean mass, and from 0.10 to $0.99 \mathrm{~g}$ for the total tissue mass (Table 2). The standard deviations of the BMC, fat and lean tissue mass showed a positive association with the absolute values (Figs. 1-3), the correlation coefficients being $r=+0.60$ $(\mathrm{p}<0.001)$ for the BMC, $r=+0.52(\mathrm{p}<0.001)$ for the fat

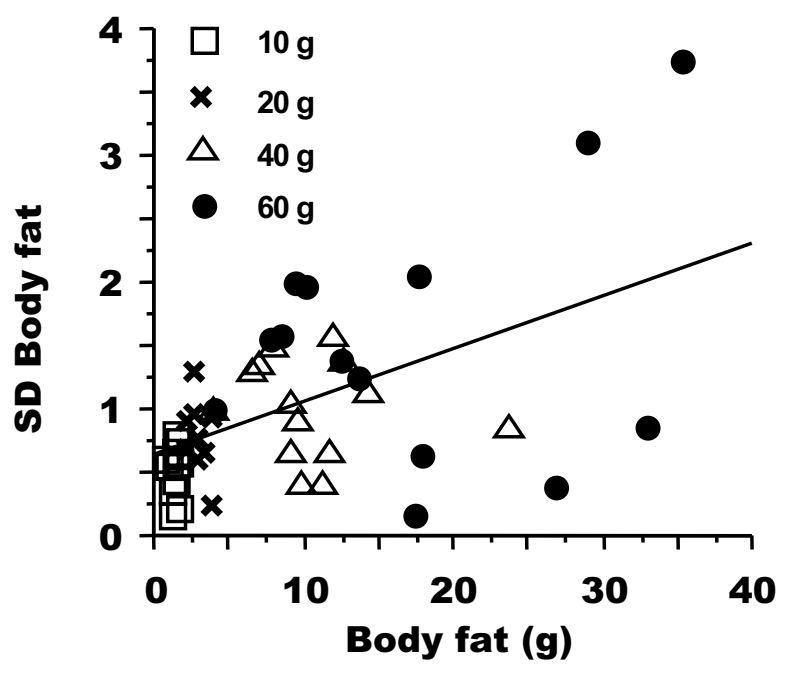

Figure 3. Graph showing the standard deviations of four repeated measurements of fat tissue mass in mice as a function of the absolute values. Same conditions and groups as indicated in the legend of Figure 1.

tissue mass, and $\mathrm{r}=+0.28(\mathrm{p}<0.05)$ for the lean tissue mass. For the BMC, the positive correlation between the standard deviations and the absolute values were also maintained when eliminating the $10 \mathrm{~g}$ animals and the two outliers in the $60 \mathrm{~g}$ group (Fig. 1); however there was no significant association between the $\mathrm{SD}$ and the absolute values for the $\mathrm{BMD}(\mathrm{r}=-0.11)$.

When being expressed as coefficients of variation, the values were highest in the $10 \mathrm{~g}$ mice, due to the low absolute values. They were lower in $20 \mathrm{~g}$ mice, and even lower in 40 and $60 \mathrm{~g}$ mice, the coefficients in the last two groups being in a similar range (Table 3 ). The coefficients of variation for the BMC were not significantly different in the 


\begin{tabular}{|c|c|c|c|c|c|c|}
\hline & BMC & BMD & $\begin{array}{l}\text { Fat } \\
\text { Mass }\end{array}$ & $\begin{array}{l}\text { Lean } \\
\text { Mass }\end{array}$ & $\begin{array}{l}\text { Total Tissue } \\
\text { Mass }\end{array}$ & $\begin{array}{l}\text { Total Tissue } \\
\text { Diff to *(\%) }\end{array}$ \\
\hline $\begin{array}{l}\text { Group } 1 \\
{[10 \mathrm{~g} \text { mice }]}\end{array}$ & $\begin{array}{l}12.8 \% \\
(2.8 / 23.6)\end{array}$ & $\begin{array}{l}4.9 \% \\
(2.8 / 8.3)\end{array}$ & $\begin{array}{l}47.5 \% \\
(12.7 / 76.7)\end{array}$ & $\begin{array}{l}18.8 \% \\
(12.2 / 29.7)\end{array}$ & $\begin{array}{l}8.3 \% \\
(12.2 / 29.7)\end{array}$ & $\begin{array}{l}-19.2 \% \\
(-24 /-14)\end{array}$ \\
\hline $\begin{array}{l}\text { Group } 2 \\
{[20 \text { g mice] }}\end{array}$ & $\begin{array}{l}9.7 \% \\
(2.1 / 18.4)\end{array}$ & $\begin{array}{l}4.5 \% \\
(1.9 / 6.4)\end{array}$ & $\begin{array}{l}28.3 \% \\
(5.4 / 43.6)\end{array}$ & $\begin{array}{l}5.9 \% \\
(2.5 / 9.2)\end{array}$ & $\begin{array}{l}1.6 \% \\
(0.5 / 3.2)\end{array}$ & $\begin{array}{l}-4.7 \% \\
(-7.2 /-2.4)\end{array}$ \\
\hline $\begin{array}{l}\text { Group } 3 \\
{[40 \text { g mice }]}\end{array}$ & $\begin{array}{l}3.5 \% \\
(1.18 / 6.68)\end{array}$ & $\begin{array}{l}1.7 \% \\
(0.7 / 2.9)\end{array}$ & $\begin{array}{l}13.5 \% \\
(3.5 / 24.4)\end{array}$ & $\begin{array}{l}5.0 \% \\
(1.2 / 6.7)\end{array}$ & $\begin{array}{l}0.9 \% \\
(0.4 / 1.8)\end{array}$ & $\begin{array}{l}-6.6 \% \\
(-8.6 /-4.1)\end{array}$ \\
\hline $\begin{array}{l}\text { Group } 4 \\
\text { [60 g mice] }\end{array}$ & $\begin{array}{l}5.6 \% \\
(1.1 / 13.5)\end{array}$ & $\begin{array}{l}3.1 \% \\
(0.6 / 6.3)\end{array}$ & $\begin{array}{l}12.9 \% \\
(1.0 / 25.0)\end{array}$ & $\begin{array}{l}6.7 \% \\
(1.1 / 13.3)\end{array}$ & $\begin{array}{l}0.8 \% \\
(0.3 / 1.0)\end{array}$ & $\begin{array}{l}-3.4 \% \\
(-4.6 /-2.1)\end{array}$ \\
\hline
\end{tabular}

* Body weight measured on a high-precision scale prior to scanning (see legend of Table 1)

Table 3. Precision of the in situ analysis of the body composition and bone mineral content of mice of different body weights (group 1 to 4 ) with HR-DXA $(\mathrm{N}=48)$. Root-mean-square average of the coefficients of variation of repeated measurements (and range).

\begin{tabular}{|c|c|c|c|c|c|c|}
\hline & \multicolumn{2}{|l|}{ Mean value } & \multicolumn{2}{|c|}{ RMS average SD } & \multicolumn{2}{|c|}{ RMS average CV\% } \\
\hline & $\begin{array}{l}\text { BMC } \\
(\mathrm{mg})\end{array}$ & $\begin{array}{l}\text { BMD } \\
\left(\mathrm{mg} / \mathrm{cm}^{2}\right)\end{array}$ & $\begin{array}{l}\text { BMC } \\
(\mathrm{mg})\end{array}$ & $\begin{array}{l}\text { BMD } \\
\left(\mathrm{mg} / \mathrm{cm}^{2}\right)\end{array}$ & $\begin{array}{l}\text { BMC } \\
(\mathrm{mg})\end{array}$ & $\begin{array}{l}\text { BMD } \\
\left(\mathrm{mg} / \mathrm{cm}^{2}\right)\end{array}$ \\
\hline $\begin{array}{l}\text { Lower } \\
\text { Body }\end{array}$ & $\begin{array}{l}1384 \pm 96 \\
(1211 / 1561)\end{array}$ & $\begin{array}{l}87.7 \pm 3.4 \\
(92 / 116)\end{array}$ & $\begin{array}{l}33.9 \\
(21.6 / \\
49.1)\end{array}$ & $\begin{array}{l}1.1 \\
(0.4 / 1.7)\end{array}$ & $\begin{array}{l}2.5 \% \\
(1.6 / 3.7)\end{array}$ & $\begin{array}{l}1.2 \% \\
(0.4 / 1.8)\end{array}$ \\
\hline $\begin{array}{l}\text { Lumbar } \\
\text { Spine }\end{array}$ & $\begin{array}{l}320 \pm 38.7 \\
(275 / 405)\end{array}$ & $\begin{array}{l}104 \pm 6.0 \\
(92 / 116)\end{array}$ & $\begin{array}{l}25.1 \\
(4.8 / 56.9)\end{array}$ & $\begin{array}{l}3.1 \\
(1.5 / 4.6)\end{array}$ & $\begin{array}{l}7.1 \% \\
(1.6 / 14.0)\end{array}$ & $\begin{array}{l}3.0 \% \\
(1.3 / 4.5)\end{array}$ \\
\hline Femur & $\begin{array}{l}212 \pm 12.3 \\
(189 / 235)\end{array}$ & $\begin{array}{l}101 \pm 4.6 \\
(96 / 110)\end{array}$ & $\begin{array}{l}12.0 \\
(7.2 / 15.9)\end{array}$ & $\begin{array}{l}2.03 \\
(0.9 / 2.6)\end{array}$ & $\begin{array}{l}5.7 \% \\
(3.3 / 8.4)\end{array}$ & $\begin{array}{l}2.0 \% \\
(0.9 / 2.7)\end{array}$ \\
\hline Tibia & $\begin{array}{l}170 \pm 8.7 \\
(154 / 175)\end{array}$ & $\begin{array}{l}99.6 \pm 4.6 \\
(95 / 107)\end{array}$ & $\begin{array}{l}6.16 \% \\
(3.3 / 9.8)\end{array}$ & $\begin{array}{l}2.08 \% \\
(1.5 / 2.9)\end{array}$ & $\begin{array}{l}3.6 \% \\
(1.9 / 5.3)\end{array}$ & $\begin{array}{l}2.1 \% \\
(1.5 / 3.1)\end{array}$ \\
\hline
\end{tabular}

Mean values and root-mean-square (RMS) average of the standard deviations (SD) and coefficients of variation (CV\%) of 4 repeated measurements in 10 animals with a body weight range of $128 \mathrm{~g}$ to $153 \mathrm{~g}$. The values in brackets give the range (minima and maxima).

Table 4. Results and precision of the in situ analysis of rodent lower body skeleton, lumbar spine, femur, and tibia with HR-DXA (spatial resolution $0.5 \times 1.0 \mathrm{~mm}$ ).

40 and $60 \mathrm{~g}$ groups, but those for the BMD were lower in the $40 \mathrm{~g}$ group $(\mathrm{p}<0.01)$. The difference disappeared, however, when eliminating the three outliers in the $60 \mathrm{~g}$ group, and this also applied to the standard deviations of the BMD (Fig. 2).

When relating the standard deviations and coefficients of variations of repeated measurements to the differences between and within the groups, it is evident that these are in the same range as the variability between the animals in group 1 and 2 (10 g and $20 \mathrm{~g}$ mice), respectively, but lower than the differences between the two groups. In groups 3 and 4 (40 g and $60 \mathrm{~g}$ mice), however, the standard deviation and coefficients of variation were found to be considerably lower than the variation between the animals within both groups.

In situ analysis of rodent lower body skeleton, lumbar spine, femur, and tibia

In the rat, the precision of bone mineral content analysis in the lower body skeleton was 3.9\% (BMD 2.7\%)

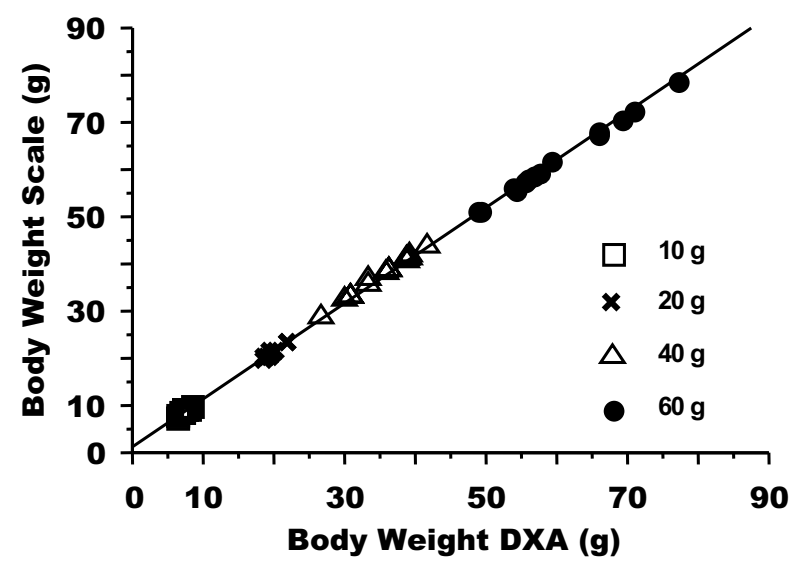

Figure 4. Correlation between the total body mass determined on a high-precision scale and with DXA (BMC + fat tissue content + lean tissue content). The correlation coefficients ranged from 0.92 in the $10 \mathrm{~g}$ mice to 0.99 in the $60 \mathrm{~g}$ mice. 
when including the lumbar spine, and $2.5 \%$ (BMD $1.2 \%$ ) when not including the spine but only the pelvis and lower extremities (Table 4). The root-mean-square average SD and $\mathrm{CV} \%$ for the BMC were highest in the spine, and lowest in the tibia, the values ranging from 3.3 to $56.9 \mathrm{mg}$, and from $1.6 \%$ to $14.0 \%$ (Table 4 ). For the BMD, the values were similar in the femur and tibia (RMS average CV \% around $2 \%$ ), but somewhat higher in the lumbar spine (RMS average $\mathrm{CV} \%=3.0 \%$ ) (Table 4 ).

\section{Discussion}

In the current study we have determined the precision of non-destructive measurements of the body composition of mice with different body weights ( $10 \mathrm{~g}$ to $60 \mathrm{~g}$ ), and of the bone mineral status in the lower body half, lumbar spine, femora and tibiae of rats weighing $137 \pm 6.9 \mathrm{~g}$. Measurements in both animal models were performed under in situ conditions (with surrounding soft tissues) and at imaging times of less than $20 \mathrm{~min}$, so that the results can be readily transferred to in vivo analysis in anaesthetized animals. Repeated measurements were not performed on the same day, but on different days after recalibration of the scanner and repositioning of the animals. From the work of Glüer et al. (1995) it can be derived that, with four repeated measurements, the degrees of freedom for precision analyses in groups of 10 to 14 animals vary between 30 and 42, and that the RMS-average $\mathrm{SD} / \mathrm{CV} \%$ values obtained under these conditions are within $\pm 30 \%$ of the true $\mathrm{SD} / \mathrm{CV} \%$ in the total population ( $95 \%$ confidence). The precision errors reported in this study can thus be taken as representative for measurements in larger populations, given that the same physical conditions (scanner hard- and software, scanner settings, supine positioning of the animals etc.) are applied. When comparing our results with the literature, it should be kept in mind that in other studies the precision was partly established under ex situ rather under in situ conditions, without repositioning of the bones, without calibration of the system, in very small numbers of animals, and by giving the arithmetic mean rather than the root mean square average $\mathrm{SD}$ and $\mathrm{CV} \%$. In this context, the present analysis is to be seen as a relatively "conservative" estimate of the actual precision error.

\section{In situ analysis of entire mice}

Our results show that in mice measurements of the total skeleton can be performed with moderate precision in $10 \mathrm{~g}$ and $20 \mathrm{~g}$ animals, and with good precision in $40 \mathrm{~g}$ and $60 \mathrm{~g}$ animals. Preliminary work has shown that no measurements could be obtained in mice of $5 \mathrm{~g}$ body weight, even at scanning times that exceeded half an hour. Based on the standard deviations and coefficients of variation of repeated measurements obtained in this study, we conclude that for mice of $10 \mathrm{~g}$ and $20 \mathrm{~g}$ the precision is high enough to demonstrate differences between groups of different body weights, but that the precision is insufficient to reliably differentiate between animals within these groups of normal outbred mice. At higher body weights, however, animals with low and high bone mineral content can be accurately differentiated, even within groups of animals of the same back- ground and similar body weights. Although the standard deviations of repeated measurements were positively correlated with the absolute values (except for the BMD) and the measurement variation was thus higher in animals with higher body weights, the relative error (coefficient of variation) became considerably smaller, due to the larger mean values in the heavier animals. A similar trend was also found in rats covering a weight range of 150 to $600 \mathrm{~g}$ (Makan et al., 1997), higher standard deviations being observed for the lean and fat tissue mass in the heavier animals. Makan et al. (1997) found, however, the standard deviation of the BMC and the coefficients of variation to be independent of body weight in their analysis.

Our study shows that the standard deviation of repeated measurements of the bone mineral content varied from a mean of $11 \mathrm{mg}$ in $10 \mathrm{~g}$ mice to $94 \mathrm{mg}$ in the $60 \mathrm{~g}$ mice (RMS average SD), whereas the mean values were $87 \pm$ $6.5 \mathrm{mg}$ in the $10 \mathrm{~g}$ animals, and $1654 \pm 265 \mathrm{mg}$ in the $60 \mathrm{~g}$ MT-bGH transgenic mice. The average measurement variation (SD) was $35 \mathrm{mg}$ in normal adult outbred NMRI mice, and their mean bone mineral content approx. $1000 \mathrm{mg}$, resulting in a coefficient of variation of $3.5 \%$. These coefficients fall somewhat short of those determined for the BMC and BMD in humans (Genant et al., 1996; Adam et al., 1997) and larger animals (Brunton et al., 1993; Grier et al., 1996; Makan et al., 1997), but the standard deviations of repeated measurements are considerably lower. Given the much smaller bone dimensions in mice and the higher requirements with regard to the spatial resolution, these values are surprisingly low and underline the usefulness of DXA measurements in cross-sectional and longitudinal studies of small animals. We can infer from the present analysis that changes of the bone mineral content of approx. $100 \mathrm{mg}(10 \%)$ can be determined with $95 \%$ confidence in a single animal (based on two measurements) and that a number of approx. 80 animals would be required to detect a $1 \%$ change of total body BMC at a significance level of 5\% (Grier et al., 1996). The smallest percentage change detectable with $95 \%$ confidence for a group of 10 animals is in the range of the 1 -fold $\mathrm{CV} \%$; therefore, the changes that can be picked up with statistical reliability in a longitudinal study with 10 mice, can be derived directly for the various parameters and body weight from Table 3 .

The precision values reported are also of crucial relevance for cross-sectional mutagenesis screening programs (Hrabé de Angelis et al., 2000), in which individual animals with an exceptional phenotype (low or high bone mineral content) need to be selected under in vivo conditions for breeding, crossing and further genetic analyses. Obviously it is possible to quantify smaller differences when performing multiple measurements in the animals. Given the reported measurement error in adult mice, it is clear that relatively small differences of bone mineral content and body composition can be reliably detected, for instance in a group of knock-out or transgenic mice. In younger mice with smaller body weight and BMC, however, several measurements should be carried out, in order to reliably determine phenotypic differences between genetically different animals. 
The precision of the BMD $\left(\mathrm{g} / \mathrm{cm}^{2}\right)$ was always higher than that of the BMC. However, despite this parameter has been termed "density" in the DXA-terminology, it must be kept in mind that it is a projectional value of bone mass per square centimeter. Although the BMC values were 20 fold higher in 60 mice than in $10 \mathrm{~g}$ mice, the BMD was only twice as high. However, the linear correlation coefficient between the BMD and the BMC was 0.95 throughout the 48 mice examined, and that between the BMD and the projectional area of the bones 0.92 . This clearly demonstrates that the BMD is dependent on bone size. Owing to the higher precision, the BMD is useful in cross-sectional or longitudinal studies in which bone size is a constant factor, but it should not be compared between animals of different body dimensions. In this case, the bone mineral status should be compared by calculating, for instance, the percentage of bone mineral relative to the total body weight. Since the precision of body mass measurements in DXA is very high, the \%BMC displays the same precision as the BMC itself (data not shown).

The standard deviations and coefficients of variation for the fat- and lean tissue content may appear high at first sight. However, it has to be kept in mind that the differences between the groups and even between the animals of the same background and weight are even larger, so that a reliable differentiation between animals should also be feasible for body composition parameters. The technique can thus be readily extended to the non-destructive analysis of the fat- and lean tissue content in transgenic animals or in mutagenesis screens, in order to elucidate the genetic components of obesity.

\section{In situ analysis of rodent lower body skeleton, lumbar spine, femur, and tibia}

Measuring single rat bones under in situ conditions in 15 animals weighing 125 to $400 \mathrm{~g}$, Rozenberg et al. (1995) reported coefficients of variation of $1.6 \%$ for the spinal, $4.2 \%$ for the femoral, and $6.0 \%$ for the tibial BMC without repositioning, and $6.8 \%, 3.4 \%$, and $3.6 \%$ with repositioning. When making measurements in the same bones under ex situ conditions (submerged in aqueous solution), the $\mathrm{CV} \%$ was generally below $1 \%$, indicating that the surrounding soft tissues make an important contribution to the precision errors. These results are in a similar range as those reported in our study, although most of the animals investigated by Rozenberg et al. (1995) were heavier than ours. Hagiwara et al. (1993) reported a coefficient of variation of $1.8 \%$ for total body BMC in 6 rats weighing approx. $280 \mathrm{~g}$, and Casez et al. (1994) 1.3\% for whole body BMC in 10 rats weighing 50 to $265 \mathrm{~g}$, these coefficients being somewhat lower than those found in our study for the lower extremity.

\section{Future perspectives and conclusions}

In summary, this paper demonstrates good precision of bone mineral measurements in small animals (e.g., the mouse and rat), provided that the resolution and scan speed are adapted to the size of the region of interest. A further important issue for future studies will be to determine the accuracy of the measurements versus an accepted gold standard. The comparison of a DXA-based estimate of the total tissue mass with the actual body weight (determined on a high precision laboratory scale) demonstrates that in terms of the radiographic detection of the tissue the measurements are highly accurate, at least for animals of $20 \mathrm{~g}$ body weight and more. In carcasses, Klein et al. (1998) recently reported a $30 \%$ overestimation of the chemically derived calcium content. Given that calcium constitutes less than one third of the ash weight, their measurements underestimated the ash weight by more than $50 \%$, but a high linear relationship of $r=0.98$ was reported between DXA and chemical analysis. Whether similar relationships apply for intact mice (including soft tissues) and for body composition analyses will have to be shown in future work, comparing the DXA-derived BMC fat tissue content in intact mice with ash weight and chemical fat analyses.

The advantage of the DXA technique is that it can be applied in vivo, and that the body composition (lean vs. fat tissue) can be determined in addition to bone mineral measurements. In case of mutagenesis screening programs (Hrabé de Angelis et al., 2000), the ability to measure changes in vivo is an indispensable prerequisite, since the animals have to be available for further breeding and genetic analyses. In case of the phenotypic characterization of transgenic and knock-out animals, experiments can be performed under ex vivo conditions, but the advantage of in situ analysis is that the skeleton stays intact and can be used for further analyses, e.g. histology or biomechanical testing. More importantly, the noninvasive nature of DXA makes it possible to study effects of various genes and gene products at different stages of development and growth in longitudinal studies. It should be kept in mind that DXA provides an integral measurement of cortical and trabecular bone, but not of structural properties of these compartments. It may therefore be useful to complement the DXA measurements with high-resolution quantitative computed tomography (QCT) (e.g., Beamer et al., 1996; Rosen et al., 1997) or micro-CT (e.g. Kinney et al., 1998; Kapadia et al., 1998; Graichen et al. 1999). However, the advantage of DXA is that the measurements are representative for an entire bone or even the entire skeleton, and not only for one specific measurement site.

In conclusion we have established a good precision of bone mineral and body composition measurements in mice and rats, using a dedicated high-resolution DXA system. Due to its non-invasive nature, the technique provides an elegant and efficient tool for testing the efficacy of drugs in small animals (e.g., the ovariectomized rat model) and for developing new compounds based on identification of the key molecular targets in mutagenesis screening programs or by generation and phenotypic characterization of transgenic animals.

\section{Acknowledgements}

We would like to express our gratitude to Sabine Mühlsimer (Musculoskeletal Research Group, Institute of Anatomy Munich) for her help with measuring the data, Petra Renner and Ingrid Renner-Müller (Institut für Molekulare Tierzucht 
und Haustiergenetik, Genzentrum der LMU München) for the excellent animal care taking and veterinary management, the Ludwig-Maximilians Universität München for funding this work, and Stratec Medizintechnik, (Pforzheim, Germany) for supporting this investigation.

\section{References}

Abe T, Chow JW, Lean JM, Chambers TJ (1993) Estrogen does not restore bone lost after ovariectomy in the rat. J Bone Miner Res 8: 831-838

Adams JE (1997) Single and dual energy X-ray absorptiometry. Eur Radiol 7 (Suppl 2): 20-31

Amling M, Hentz MW, Priemel M, Delling G (1998) Transgenic and gene knock-out animals in skeletal research. In: Novel approaches to treatment of osteoporosis. Russel RGG, Skerry TM, Kollenkirchen U, eds. Springer, Berlin. pp. 123-155

Beamer WG, Donahue LR, Rosen CJ, Baylink DJ (1996) Genetic variability in adult bone density among inbred strains of mice. Bone 18: 397-403.

Brunton JA, Bayley HS, Atkinson SA (1993) Body composition analysis by dual energy $\mathrm{X}$ ray absorptio-metry compared to chemical analysis of fat, lean and bone mass in small piglets. Basic Life Sci 60: 157-160.

Casez JP, Muehlbauer RC, Lippuner K, Kelly T, Fleisch H, Jaeger P (1994) Dual energy X ray absorptiometry for measuring total bone mineral content in the rat: study of accuracy and precision. Bone Miner 26: 61-68.

Chang AWS (1999) Transgenic animals: Current and alternative strategies. Cloning 1: 25-46.

Chow JW, Lean JM, Chambers TJ (1992) 17 beta estradiol stimulates cancellous bone formation in female rats. Endocrinology 130: 3025-3032.

Cooper C, Barret-Connor E (1996) Epidemiolgy of Osteoporosis. In: Osteoporosis '96, International Congress Series 118, Excerpta Medica. Papapoulos SE, Lips P, Pols HAP, Johnston CC, Delmas PD (eds.). Elsevier, Amsterdam. pp. 75-78.

Cooper C, Campion G, Melton LJ (1992) Hip fractures in the elderly: a world wide projection. Osteoporosis Int 2: 285-289.

Genant HK, Engelke K, Fuerst T, Gluer CC, Grampp S, Harris ST, Jergas M, Lang T, Lu Y, Majumdar S, Mathur A, Takada M (1996) Noninvasive assessment of bone mineral and structure: state of the art. J Bone Miner Res 11: 707-730.

Glüer CC, Blake G, Lu Y, Blunt BA, Jergas M, Genant HK (1995) Accurate assessment of precision errors: How to measure the reproducibility of bone densitometry techniques. Osteoporosis Int 5: 262-270.

Graichen H, Lochmüller EM, Wolf E, Langkabel B, Stammberger T, Haubner M, Renner-Müller I, Englmeier KH, Eckstein F (1999) A non-destructive technique for 3$\mathrm{D}$ microstructural phenotypic characterisation of bones in genetically altered mice-preliminary data in growth hormone transgenic animals and normal controls. Anat Embryol 199: 239-248.

Grier SJ, Turner AS, Alvis MR (1996) The use of dual energy x ray absorptiometry in animals. Invest Radiol 31: 50-62.

Hagiwara S, Lane N, Engelke K, Sebastian A, Kimmel DB, Genant HK (1993) Precision and accuracy for rat whole body and femur bone mineral determination with dual X ray absorptiometry. Bone Miner 22: 57-68.

Hrabé de Angelis M, Flaswinkel H, Fuchs H, Rathkolb B, Soewarto D, Marschall S, Heffner S, Pargent W, Wuensch K, Jung M, Reis A, Richter T, Alessandrini F, Jakob T, Fuchs E, Kolb H, Kremmer E, Schaeble K, Rollinski B, Roscher A, Peters C, Meitinger T, Strom T, Steckler T, Holsboer F, Klopstock T, Gekeler F, Schindewolf C, Jung T, Avraham K, Behrendt H, Ring J, Zimmer A, Schughart K, Pfeffer K, Wolf E, Balling R (2000) Genome-wide, large-scale production of mutant mice by ENU mutagenesis. Nature Genet 25: 444-447.

Kalu DN (1991) The ovariectomized rat model of postmenopausal bone loss. Bone Miner 15: 175-191.

Kapadia RD, Stroup GB, Badger AM, Koller B, Levin JM, Coatney RW, Dodds RA, Liang X, Lark MW, Gowen M (1998) Applications of micro-CT and MR microscopy to study pre-clinical models of osteoporosis and osteoarthritis. Techn Health Care 6: 361-372.

Kinney JH, Ryaby JT, Haupt DL, Lane NE (1998) Three-dimensional in vivo morphometry of trabecular bone in the OVX rat model of osteoporosis. Techn Health Care 6: $339-350$.

Klein RF, Mitschell SR, Phillips TJ, Belknap JK, Orwell ES (1998) Quantitative trait loci affecting peak bone mineral density in mice. J Bone Miner Res 13: 1648-1656.

Makan S, Bayley HS, Webber CE (1997) Precision and accuracy of total body bone mass and body composition measurements in the rat using $\mathrm{x}$ ray based dual photon absorptiometry. Can J Physiol Pharmacol 75: 1257-1261.

Melton, L J, Thamer NF, Ray JK, Chesnut CH, Einhorn TA, Johnston CC, Raiz LG, Silverman SL, Siris ES (1997) Fractures attributable to osteoporosis: Report from the National Osteoporosis Foundation. J Bone Miner Res 12: 16-23.

Mundy GR (1998) What can we learn from bone biology for the treatment of osteoporosis. Osteoporosis Int 8 (Suppl 3): 2 [abstract].

Ray NF, Chan J, Thamer M., Melton LJ (1997) Medical expenditures for the treatment of osteoporotic fractures in the United States in 1995: Report from the National Osteoporosis Foundation. J Bone Miner Res 12: 24-35.

Rose BS, Flatt WP, Martin RJ, Lewis RD (1998) Whole body composition of rats determined by dual-energy Xray absorptiometry is correlated with chemical analysis. $\mathrm{J}$ Nutr 128: 246-250.

Rosen CJ, Dimal HP, Vereault D, Donahue LR, Beamer WG, Farley J, Linkhart S, Linkhart T, Mohan S, Baylink DJ (1997) Circulating and skeletal insulin-like growth factor I (IGF-I) concentrations in two inbred strains of mice with different bone mineral densities. Bone 21: 217-223.

Rossant J, Nagy A (1995) Genome engineering: the new mouse genetics. Nature Med 1: 592-594.

Rozenberg S, Vandromme J, Neve J, Aguilera A, Muregancuro A, Peretz A, Kinthaert J, Ham H (1995) Precision and accuracy of in vivo bone mineral measurment 
in rats using dual-energy X-ray absorptiometry. Osteoporosis Int 5: 47-53.

Shen V, Birchman R, Xu R, Otter M, Wu D, Lindsay R, Dempster DW (1995) Effects of reciprocal treatment with estrogen and estrogen plus parathyroid hormone on bone structure and strength in ovariectomized rats. J Clin Invest 9: 2331-2338.

Wynshaw-Boris A (1996) Model mice and human disease. Nature Genet 13: 259-260.

\section{Discussion with Reviewers}

M. Amling: As the authors mention in "Future perspectives and conclusions" the validation with a gold standard remains to be done. The only validated data yet is the comparison with total body weight measured on a high precision scale. Here the authors report an underestimation of body weight by DXA of up to $20 \%$ in the $10 \mathrm{~g}$ group. As long as we don't have a validation for the real bone density/mass, e.g. by comparison with histomorphometry, the underestimation with respect to body weight suggests a similar problem when assessing bone density.

Authors: It is correct that the validation of bone mineral and body composition analysis remains to be established. Bone mineral content (BMC) will be validated against ash weight, and fat tissue content from DXA against the chemically derived fat tissue content after homogenization of animals. This work is currently in progress. It is also correct that BMD may be compared to histomorphometry, but we anticipate discrepancy between the two methods, since histomorphometry determines bone volume fraction (morphological density) in the trabecular compartment, whereas as BMD in DXA determines bone mass divided by the projectional area of the bone in the cortical and trabecular compartment taken together.

M. Amling: Between groups the authors use different scanning speeds and resolutions. Please comment on comparability of data between these groups.

Authors: We have performed comparisons between different resolutions and scanning speeds in single animals and found little differences; however, we have not performed a thorough analysis in a large set of animals, to be able to evaluate this issue statistically. The reason for using different resolutions and scanning speeds was a) variations in the size of the animals and b) the time restrictions for the DXA scans:

ad a) The maximal resolution applicable is that of the length of the animal that needs to fit in the measurement field divided by the matrix (255 pixels). Animals up to a size of $12.5 \mathrm{~cm}$ can thus be examined at a $0.5 \times 0.5 \mathrm{~mm}$ resolution, whereas animals with a length between 12.5 and $15 \mathrm{~cm}$ (15 cm being the maximal scanning field) can only be scanned at a $0.5 \times 1.0 \mathrm{~mm}$ resolution with the current software. Smaller animals should, however, be scanned with the higher resolution, to reduce partial volume effects.

ad b) Presumably, the precision errors increase with higher scanning speeds, particularly in smaller animals. We attempted not to exceed a total scanning time of $20 \mathrm{~min}$ for each animal, so that the results of this study can be readily transferred to an in vivo setting, in which animals can be anesthetized by intraperitoneal injection for a similar period. Since the total scan time also depends on the size of the animal, we would have exceeded $20 \mathrm{~min}$. with using lower speeds in the 40 and $60 \mathrm{~g}$ animals. If we had used higher scanning speeds in the smaller animals, the precision errors may have been higher than the ones currently reported. However, since the scan time did not exceed 20 min. in the smaller mice, there was no reason for using higher speeds.

M. Amling: Please comment, why underestimation of body weight (1-2 g) does not seem to be related to body weight in contrast to all other values.

Authors: It is correct that the absolute underestimation of the body weight by DXA (in g) was not related to the weight of the animals, whereas the percent difference was higher in animals with lower body weight. This may be similar for a potential underestimation of the bone mineral or fat tissue content, but as discussed above, the accuracy of bone mineral and fat tissue analyses have not yet been examined. The precision errors (standard deviations of repeated measurements) of the $\mathrm{BMC}$, and fat tissue content were higher in animals with higher body mass, whereas the precision errors of the BMD and total body weight were not. The reason for the BMD errors being independent of body weight is most likely because the values are normalized to projectional bone areas, which also scale with body weight.

M. Priemel: As mentioned by the authors, the lack of information regarding cortical and trabecular bone structure limits the high-resolution DXA analysis. Furthermore, it is of interest, which relative changes in bone volume fraction can be detected by high resolution DXA measurements, especially in view of models with only slight changes in bone volume fraction or structure. The high resolution DXA analysis further has to be challenged by different transgenic, knock-out or treatment animal models to test the value of this method.

Authors: It is correct that the ability of the DXA system to detect changes longitudinally or between different groups of animals will have to be assessed in further studies. The results should be compared to histomorphometry or highresolution pQCT (peripheral quantitative computed tomography), which can also be applied in vivo, and - unlike DXA - allow for a differentiation between cortical and trabecular bone changes. 